\title{
The first fossil wedge-shaped beetle (Coleoptera, Ripiphoridae) from the middle Jurassic of China
}

\author{
Yun HSIAO ${ }^{1}$, Yali YU ${ }^{2}$, Congshuang $\mathrm{DENG}^{3}$ \& Hong PANG ${ }^{4, *}$ \\ ${ }^{1}$ Department of Entomology, National Taiwan University, No. 27, Lane 113, \\ Sec. 4, Roosevelt Rd., Taipei 10617, Taiwan. \\ ${ }^{1,2,3,4}$ State Key Laboratory of Biocontrol, Ecology and Evolution, School of Life Sciences, \\ Sun Yat-Sen University, Guangzhou 510275, Guangdong, China. \\ ${ }^{2,3}$ College of Life Sciences, Capital Normal University, Xisanhuanbeilu 105, \\ Haidian District, Beijing 100048, China. \\ ${ }^{1}$ Email: yunhsiao@outlook.com \\ 2Email: yuyali2934@126.com \\ ${ }^{3}$ Email: dengcsh@mail2.sysu.edu.cn \\ ${ }^{*}$ Corresponding author: Lsshpang@mail.sysu.edu.cn \\ ${ }^{1}$ urn:1sid:zoobank.org:author:6E5C734A-1809-46A1-A595-5A0CB7B39BA0 \\ ${ }^{2}$ urn:1sid:zoobank.org:author:27B5250D-9105-4453-A838-7BD1CA184626 \\ ${ }^{3}$ urn:1sid:zoobank.org:author:38CB4386-FA6B-45F6-B525-390EB866C443 \\ ${ }^{4}$ urn:1sid:zoobank.org:author:9C71F61F-31A9-4296-91A6-B3D67168BD3D
}

\begin{abstract}
A new species of Ripiphoridae Gemminger \& Harold, 1870, Archaeoripiphorus nuwa gen. et sp. nov., is described and illustrated from a well-preserved impression fossil from the Middle Jurassic Jiulongshan Formation collected at Daohugou Village, Shantou Township, Ningcheng County, Inner Mongolia, China, representing the oldest documented occurrence of the Ripiphoridae described from the Mesozoic era. It shares several characters belonging to two basal ripiphorid subfamilies (Pelecotominae and Ptilophorinae), but it cannot be attributed to either of them and is herein placed as Subfamily incertae sedis. An overall similarity between Archaeoripiphorus gen. nov. and Recent Pelecotominae and the occurrence of wood-boring beetles in the same Formation implies a similar parasitoid host preference in xylophagous beetles for $A$. nuwa gen. et sp. nov., putting a spotlight on a potential host-parasitoid relationship in the Mesozoic.
\end{abstract}

Keywords. Coleoptera, Ripiphoridae, new fossil taxa, conjecture of natural history, Middle Jurassic.

Hsiao Y., Yu Y., Deng C \& Pang H. 2017. The first fossil wedge-shaped beetle (Coleoptera, Ripiphoridae) from the middle Jurassic of China. European Journal of Taxonomy 277: 1-13. http://dx.doi.org/10.5852/ejt.2017.277

\section{Introduction}

Beetles are the most diverse and successful organisms, well adapted to various habitats and comprising a major part of animal biodiversity on Earth. They are also abundant and speciose in the fossil record. 
The research on fossil Coleoptera was initiated in the early part of the $20^{\text {th }}$ century (e.g., Handlirsch 1906-1908); in China, work on Mesozoic fossil Coleoptera has progressed well in the past 30 years and over 200 species have been described (Tan et al. 2010). Among these fossil beetles, studies of fossil tenebrionoids are relatively few, including some species of Tenebrionidae, Mordellidae and Liaoximordellidae (Wang 1993; Huang \& Yang 1999; Liu et al. 2007, 2008; Wang \& Zhang 2011; Chang et al. 2016).

Ripiphoridae Gemminger \& Harold, 1870, also known as wedge-shaped beetles because of the wedge-shaped, humped and tapered body, are traditionally divided into 6 subfamilies: Pelecotominae, Micholaeminae, Ptilophorinae, Hemirhipidiinae, Ripidiinae, and Ripiphorinae (Lawrence \& Newton 1995). Lawrence et al. (2010) followed Falin (2003), treating Micholaeminae as part of Pelecotominae and transferring some genera of Pelecotominae to Ptilophorinae. The subfamilial classification of Falin (2003) was also followed by Batelka (2012) although Falin's study remains unpublished. Ripiphoridae includes more than 400 species in 38 genera and 5 subfamilies widely distributed worldwide (Lawrence et al. 2010). Lacordaire (1859) placed the family Ripiphoridae next to Mordellidae, and such a relationship was also discussed and suggested by Selander (1957), Franciscolo (1962), Crowson (1995) and Falin (2002). In contrast, several authors linked Ripiphoridae to Meloidae based on some adult and larval characters (Forbes 1926; Böving \& Craighead 1931; Beutel \& Friedrich 2005). Recently, some molecular phylogenetic studies have given some new insights into the phylogenetic position of Ripiphoridae. Gunter et al. (2014) used six genes to resolve family-level phylogenies of Tenebrionoidea. The results of Maximum Likelihood and Bayesian analysis supported that Ripiphoridae is sister to Mordellidae and the monophyly of the clade Ripiphoridae + Mordellidae. However, Ripiphoridae was presented as a paraphyletic group in the resultant ML tree and Bayesian tree. The same relationship was also presented in Kergoat et al. (2014) by using four mitochondrial gene fragments and four nuclear fragments in their phylogenetic analysis. McKenna et al. (2015) reconstructed a comprehensive phylogeny of beetles based on DNA sequence data from eight nuclear genes and the result provided good support for a monophyletic group including Stenotrachelidae, Lymexylidae, Aderidae, Anthicidae, Meloidae, Mordellidae and Ripiphoridae, which is in a basal position within Tenebrionoidea. Nevertheless, Mordellidae and Ripiphoridae were not recovered as sister groups, and Ripiphoridae was not even monophyletic on the ML tree. Batelka et al. (2016a) performed a comprehensive molecular phylogenetic analysis of Ripiphoridae, which was inferred from rRNA and mtDNA markers and for 23 taxa in 4 subfamilies. Ripiphoridae was still not recovered as a monophyletic group, with Mordellidae forming a terminal lineage within a paraphyletic Ripiphoridae. The clade Ripiphoridae + Mordellidae is in a basal position within Tenebrionoidea. It suggested that ripiphorid lineages gradually split basally to Mordellidae and refuted the previous hypotheses on the relationship between Meloidae and Ripiphoridae.

Fossil ripiphorid taxa are rare, and most species were described from Cenozoic ambers (Kaupp et al. 2001). Mesozoic taxa include two species from the Burmese amber (upper Cretaceous) and two from French Albo-Cenomanian ambers (mid Cretaceous) (Cockerell 1917; Perrichot et al. 2004; Falin \& Engel 2010; Batelka et al. 2016b). In the present paper, we describe a new genus and species of Ripiphoridae based on an individual preserved in the Middle Jurassic Jiulongshan Formation of Daohugou, which is composed of grey tuffaceous sandstone and sandy mudstone; the paleoenvironment is considered to have been a volcanic region with mountain streams and lakes (Ren \& Krzeminski 2002). The new genus shares several characters belonging to two Recent subfamilies (Pelecotominae and Ptilophorinae), but it cannot be attributed to either of them (see Discussion section for details). It represents the oldest fossil record for this family. We also discuss the possible natural history of this new species.

\section{Material and methods}

The sole specimen is derived from impression fossil deposits in the Daohugou Village, Shantou Township, Ningcheng County, Inner Mongolia, China. The type specimen is deposited at the Key 
Laboratory of Insect Evolution \& Environmental Changes, Capital Normal University in Beijing, China. The specimen was observed using a Nikon SMZ1270 stereo microscope. Photographs were taken using a Nikon DXM1200C digital camera and drawings prepared with a pen on a sheet of tracing paper covered on a copied figure to suitable size. Digital photographs were enhanced with Adobe Photoshop CS3 graphic software. The photographs of Trigonodera tokejii (Nomura \& Nakane, 1959) were taken at the Hokkaido University Museum (Sapporo, Japan). The morphological terminology used follows Batelka (2009) and Lawrence et al. (2010). The subfamilial classification follows Falin (2003) and Lawrence et al. (2010).

The measurements were taken as follows: (1) body length was measured from anterior margin of clypeus to the apex of elytra; width across the greatest part of elytra; (2) head length was measured from anterior margin of clypeus to posterior margin of occiput; (3) eye diameter is the greatest width of eyes; (4) antenna length was measured from the first to the last visible antennomere; (5) thorax length was the greatest length of pronotum. Absolute measurements are indicated in millimeters $(\mathrm{mm})$.

\section{Results}

\section{Systematic paleontology}

Class Hexapoda Blainville, 1816

Order Coleoptera Linnaeus, 1758

Suborder Polyphaga Emery, 1886

Superfamily Tenebrionoidea Latreille, 1802

Family Ripiphoridae Gemminger \& Harold, 1870

Subfamily Unknown (incertae sedis)

Genus Archaeoripiphorus Hsiao, Yu \& Deng gen. nov.

urn:1sid:zoobank.org:act:E2DF89AC-7896-44E8-9297-7F3792067F60

\section{Type species}

Archaeoripiphorus nuwa gen. et sp. nov.

\section{Diagnosis}

Body large-sized (about 15-16 mm); head elongate, abruptly constricted posteriorly to form broad neck; eyes oval, shallowly emarginate, distinctly separated from each other; antennae 11-segmented, antennomeres IV to X rectangular or trapezoidal and antennomere XI with pointed apex; terminal maxillary palpomere elongate securiform, not modified, about 4.0 times as long as minimum width; pronotum almost triangular, trilobed at base; elytra complete, covering entire abdomen; abdomen with five ventrites; protibiae nearly as long as protarsi; apices of tibiae without spiniform seta; claws pectinate, at least in mid and hind legs.

\section{Etymology}

The generic name is derived from the type genus of Ripiphoridae, Ripiphorus and the prefix Archaeo-, indicating ancient. Gender masculine. 
Archaeoripiphorus nuwa Hsiao, Yu \& Deng sp. nov. urn:1sid:zoobank.org:act:F5AFB48F-0494-4CEC-B7F6-2B1742AC4F34

Figs $1-4$

\section{Diagnosis}

As for the genus (vide supra). In particular this species resembles the extant ptilophorine species, Trigonodera tokejii (Nomura \& Nakane, 1959) in general appearance (Fig. 5), from which it differs by

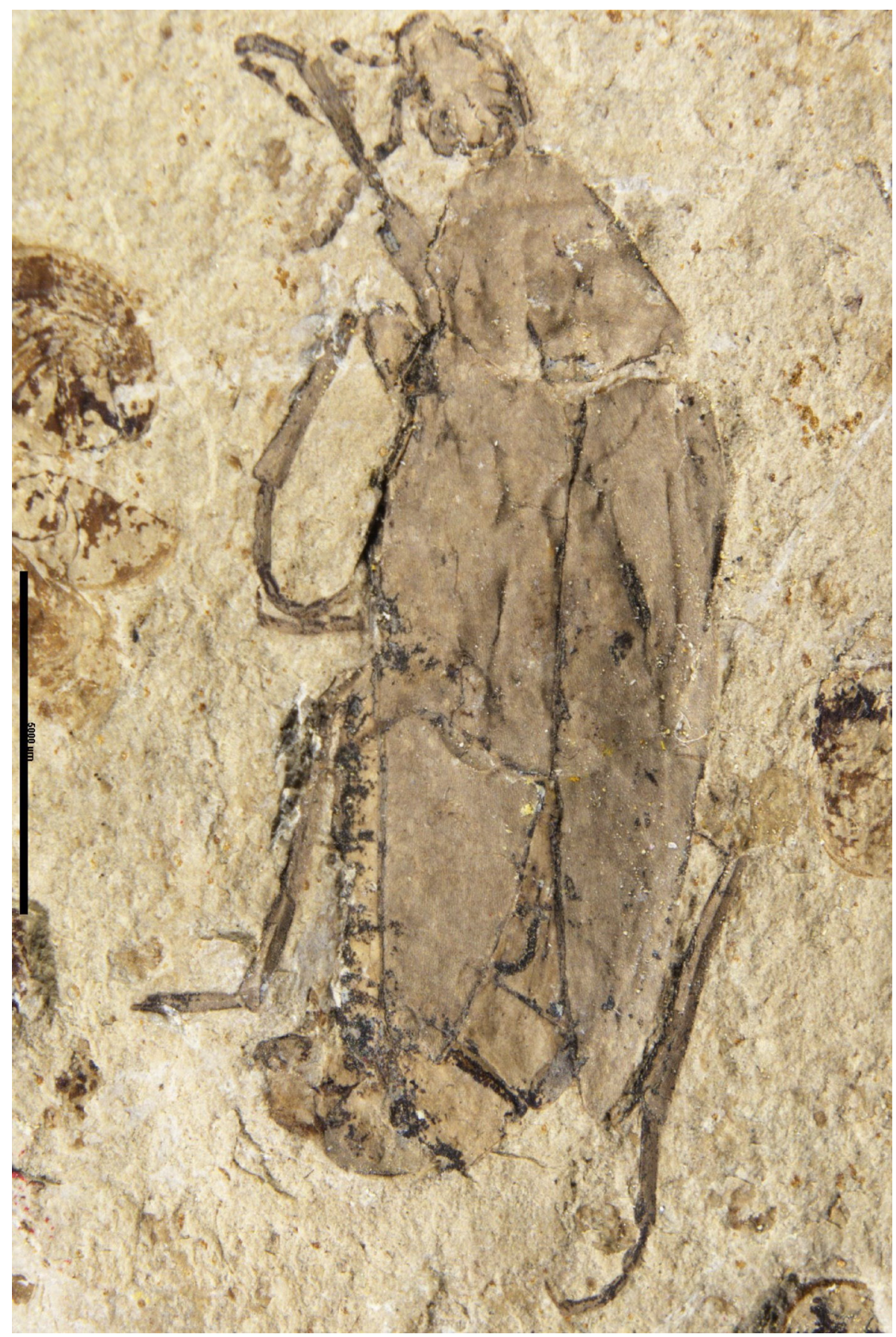

Fig. 1. Archaeoripiphorus nuwa Hsiao, Yu \& Deng gen. et sp. nov., holotype, habitus, dorsal view. Scale bar $=5.0 \mathrm{~mm}$. Photograph of dry specimen. 

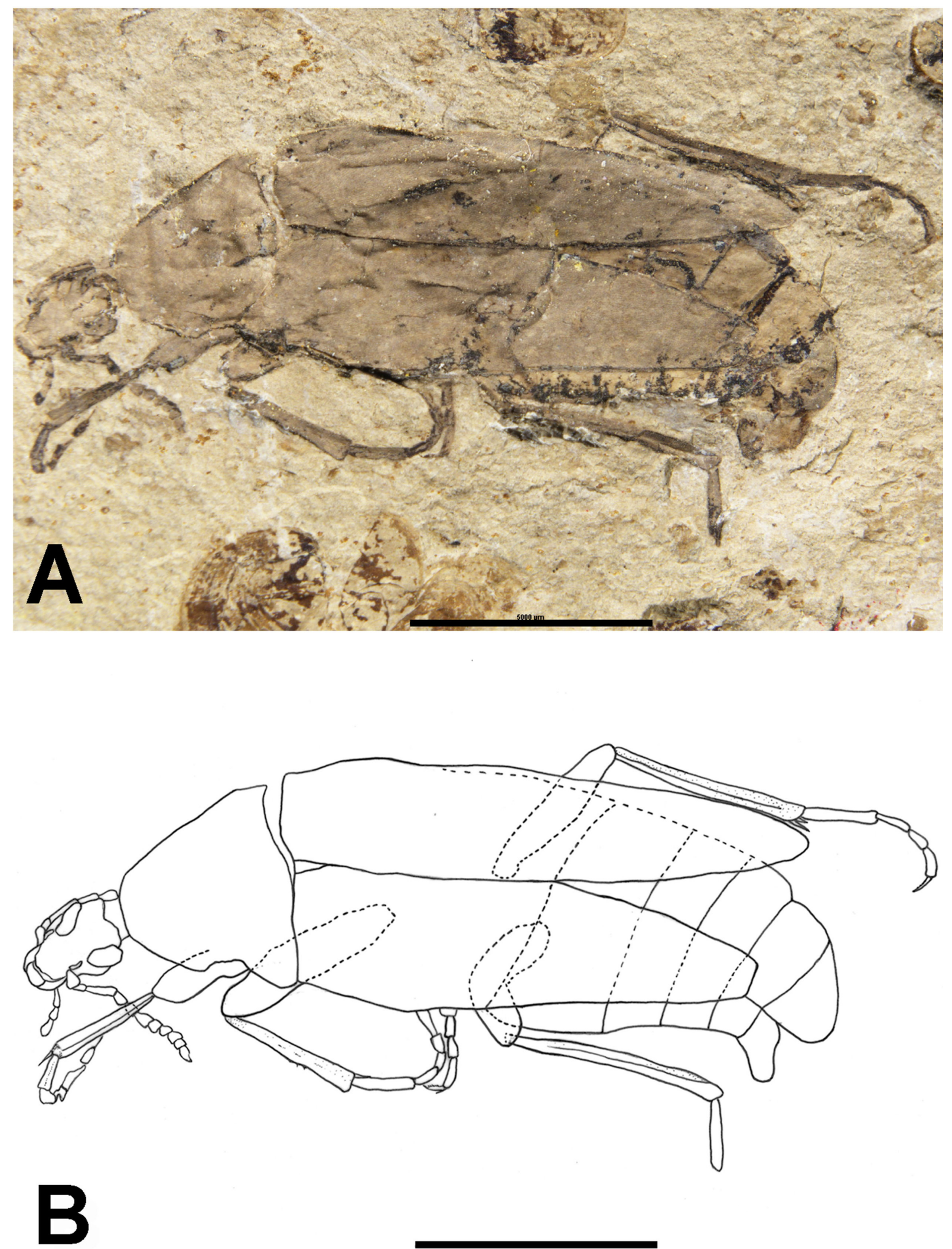

Fig. 2. Archaeoripiphorus nuwa Hsiao, Yu \& Deng gen. et sp. nov., holotype. A. Photograph of complete specimen. B. Habitus drawing. Scale bars $=5.0 \mathrm{~mm}$. 
its shorter antennae and terminal maxillary palpomere, wider pronotum anteriorly, shorter elytra, and tibial edges without spiniform seta apically.

\section{Etymology}

The specific name honors the great goddess in the ancient Chinese mythology, Nüwa, who created mankind and saved humanity from a major catastrophe by using the five-colored stones to repair the damage to the pillar of heaven caused by the water god, Gonggong.

\section{Type material}

\section{Holotype}

CHINA: nearly complete specimen in dorsal position; sex unknown (CNU-C-NN-2006841).

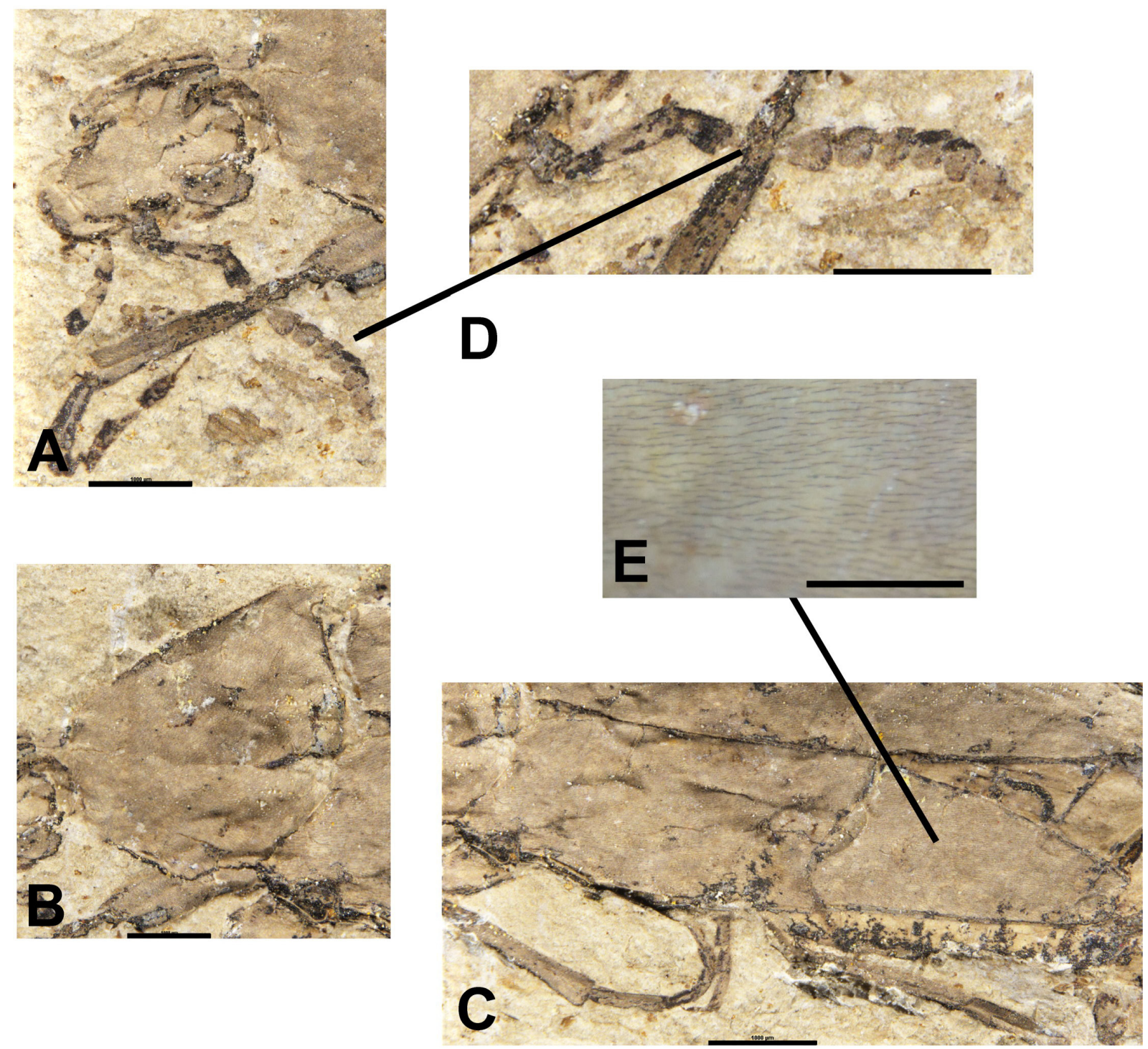

Fig. 3. Archaeoripiphorus nuwa Hsiao, Yu \& Deng gen. et sp. nov., holotype. A. Head. B. Prothorax. C. Elytron. D. Antenna. E. Photograph of the surface of the body. Scale bars: A-C $=1.0 \mathrm{~mm}$; D = $0.1 \mathrm{~mm} ; \mathrm{E}=0.5 \mathrm{~mm}$. The black arrows indicate the magnified portions. 


\section{Type locality}

CHINA: NE China, Daohugou, Shantou Township, Ningcheng County, Inner Mongolia.

\section{Type horizon}

Jiulongshan Formation, Middle Jurassic, about 165 Ma (Gao \& Ren 2006).

\section{Description}

Body (Figs 1-2). Length $15.5 \mathrm{~mm}$, width $5.0 \mathrm{~mm}$, head length $2.0 \mathrm{~mm}$, antennal length $3.4 \mathrm{~mm}$, pronotum length $3.5 \mathrm{~mm}$, pronotum width $4.0 \mathrm{~mm}$, elytra length $10.0 \mathrm{~mm}$. Surface densely covered with fine pubescence (Fig. 3E).

HEAD (Fig. 3A). Small and elongate, abruptly constricted posteriorly to form broad neck; surface sparsely punctate. Eyes oval, shallowly emarginate, distinctly separated from each other, ratio of eye diameter to interocular space 1.00:1.65; surface finely faceted. Frontoclypeal suture indistinct. Apical margin of clypeus slightly sinuate. Labrum rounded, subquadrate. Terminal maxillary palpomere elongate securiform, about 4.0 times as long as minimum width. Antennal insertions widely separated, exposed from above. Antennae 11-segmented. Scape and pedicel very short, antennomere III strongly elongate, IV to X rectangular or trapezoidal, antennomere XI with pointed apex (Fig. 3D). Length ratio of antennomeres as follows: 1.20:1.00:2.30:1.35:1.20:1.35:1.10:0.90:0.90:0.90:1.45.
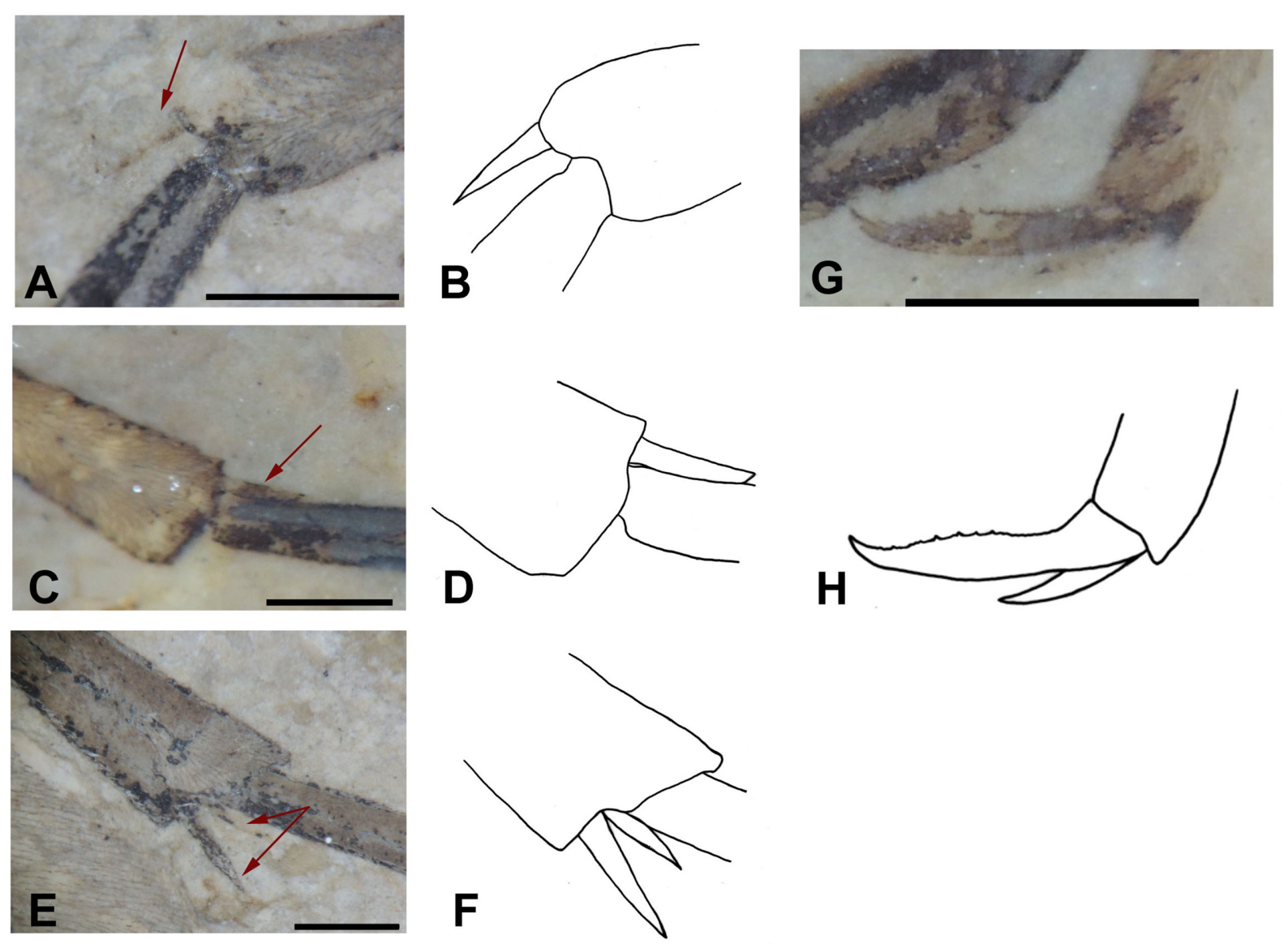

Fig. 4. Archaeoripiphorus nuwa Hsiao, Yu \& Deng gen. et sp. nov., holotype. A-F. Tibial spurs (indicated by the red arrows). A-B. Fore leg. C-D. Mid leg. E-F. Hind leg. G-H. Tarsal claw of mid leg. A, C, E, G. Photographs. B, D, F, H. Hand drawings. Scale bars: $0.5 \mathrm{~mm}$. 
Prothorax (Fig. 3B). Almost triangular, about 0.88 times as long as wide, slightly narrower than elytra at base, tapering anteriorly; anterior margin truncate and straight; anterior angles rounded and indistinct, posterior margin trilobed, with posterior angles moderately protruding and obtuse; dorsal surface densely punctate. Scutellar shield minute, angulate apically.

ELYTRA (Fig. 3C). About 2 times as long as wide, lateral sides slightly narrowing posteriorly; surface densely and regularly punctate. Abdomen with five tergites and ventrites.

LEGS. Long and slender; tibiae moderately widening apically, without spiniform seta at apices, tibial spur formula 1-1-2 (Fig. 4A-F); tarsi slender, tarsal formula 5-5-4; tarsus nearly as long as tibiae in fore and mid legs, slightly shorter than tibiae in hind legs; tarsomeres cylindrical, hind tarsomere I slightly longer than tarsomeres II and III combined. Claws slightly pectinate (Figs 4G-H).

\section{Discussion}

Archaeoripiphorus gen. nov. can be placed within Tenebrionoidea based on its wedge-shaped body and characteristic 5-5-4 tarsal formula. Our described specimen shares several characters with the tenebrionoid taxon from the same Formation, Wuhua jurassica Wang \& Zhang, 2011 (Tenebrionoidea, unknown family): oval and distinctly separated eyes, wedge-shaped body, fully developed elytra, tibial edges without spiniform seta apically and pectinate claws, but can be distinguished by its small and elongate head, elongate securiform terminal maxillary palpomere, and rectangular or trapezoidal antennomeres IV to X. Archaeoripiphorus gen. nov. also shares a general overall similarity to tenebrionoid members such as Mordellidae, Ripiphoridae, Melandryidae, Scraptiidae and Stenotrachelidae. The simple, unmodified

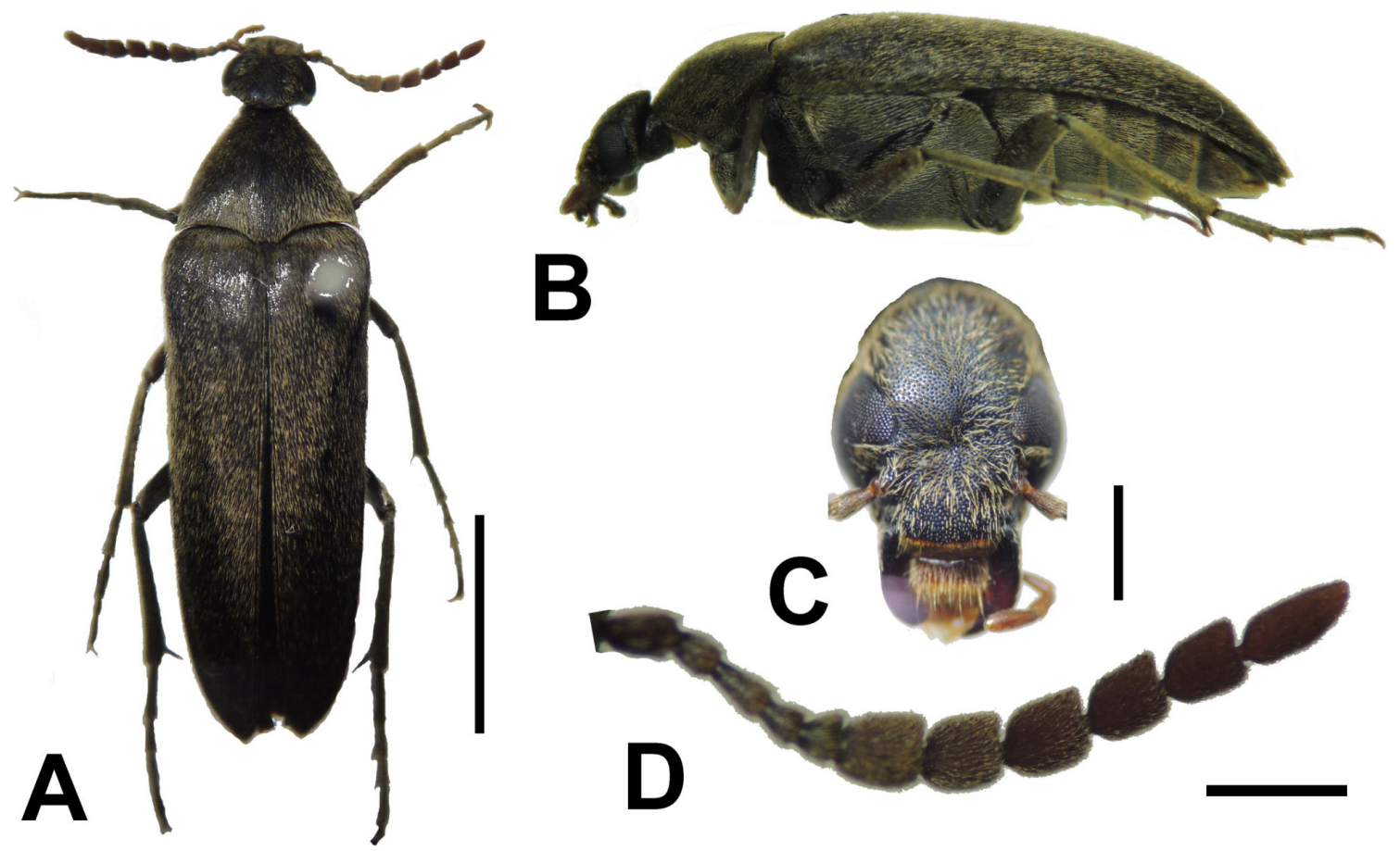

Fig. 5. An extant species of Ptilophorinae, Trigonodera tokejii (Nomura \& Nakane, 1959). A. Habitus, dorsal view. B. Habitus, lateral view. C. Head, frontal view. D. Antenna. Scale bars: A-B = $5.0 \mathrm{~mm}$; $\mathrm{C}-\mathrm{D}=1.0 \mathrm{~mm}$. 
terminal maxillary palpomere, and lack of an abdominal spine and the pulvilli of the tarsal claws suggest a placement in Ripiphoridae rather than in the above mentioned families.

However, the subfamilial attribution of this species is difficult. Obviously, this fossil species should not be attributed to either of the morphologically derived subfamilies, Ripiphorinae and Ripidiinae, by its long and complete elytra, and unexposed wings. It also cannot be placed in Hemirhipidiinae due to its not strongly incised eyes and complete elytra. Although Archaeoripiphorus gen. nov. is similar to the members of Pelecotominae and Ptilophorinae by its complete elytra and shares characters with the extant genus of Ptilophorinae, Trigonodera (Dejean, 1834) as large-sized body and pectinate claws, it differs from Pelecotominae and Ptilophorinae in the apices of tibiae without any spiniform seta, which are terminated by clusters of strong spiniform setae (as in Ptilophorus) or the rim provided with dense, regular row of strong spiniform setae in both subfamilies. Furthermore, this fossil taxon can be excluded from Pelecotominae by its elongate head, rectangular or trapezoidal antennomeres IV-X, pectinate claws and protibiae nearly as long as protarsi, which is subglobular, distinctly pectinate, bidentate or rarely with irregular serration, and shorter than protarsi, respectively, in Pelecotominae. This fossil species is also different from ptilophorine taxa because of the tibial spur formula 1-1-2, which is 2-2-2 in Ptilophorinae; it is possible that the 1-1-2 tibial spur formula was caused by overlaying of one spur on another and could be an artefact of preservation and compression. In conclusion, we herein cannot determine subfamilial attribution of Archaeoripiphorus gen. nov. and place it as subfamily incertae sedis.

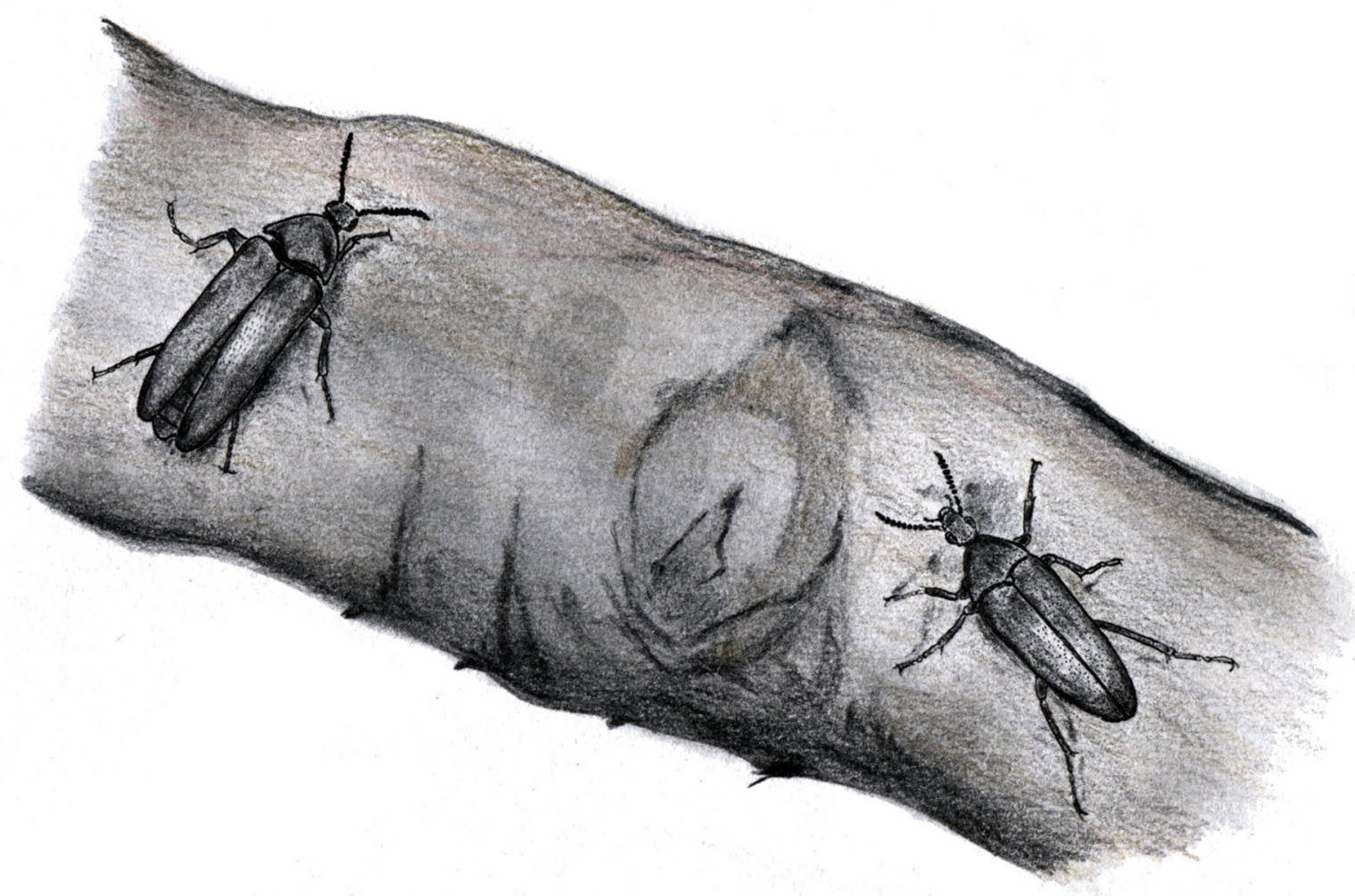

Fig. 6. A reconstruction of Archaeoripiphorus nuwa Hsiao, Yu \& Deng gen. et sp. nov., illustrating a hypothesized behavior in which the females search for damaged xylem cells, caused by larvae of xylophagous beetles, to oviposit in wood. 
The biology of Ripiphoridae is diverse and quite different from their reputed relatives. Some larvae are phoretic and some are hypermetamorphic, and parasitize other insects in all known cases. The immature stages of Pelecotominae are associated with the larvae of wood-boring beetles such as Anobiidae and Cerambycidae (Hudson 1934; Watt 1983; Kuschel 1990; Švácha 1994; Falin 2002; Batelka 2005, 2009; Lawrence et al. 2010). It is likely that the Jurassic Archaeoripiphorus gen. nov. had a similar parasitism of xylophagous beetles and oviposition behavior on woods infested with wood-boring beetles (Fig. 6) based on its overall morphological similarity to extant pelecotomine species and the occurrence of Cupedidae, Elateridae, Cerophytidae and Buprestidae in the same Formation, which possibly had woodboring larval stages (Chang et al. 2009a, b; Tan et al. 2010; Chang et al. 2011; Pan et al. 2011). On the other hand, together with the paleoenvironment at the Daohugou Village surrounded with gymnosperm forests and some angiosperms (Mi et al. 1996; Ren et al. 2010; Han et al. 2016; Liu \& Wang 2016) and the overall morphological similarity between Archaeoripiphorus nuwa Hsiao, Yu \& Deng gen. et sp. nov. and the extant ptilophorine species, T. tokejii (Nomura \& Nakane, 1959) from Japan and Taiwan (Fig. 5), which can be collected by sweeping flowers and may be a pollen feeder (S. Kakizoe pers. comm.), potential pollen-feeding of Archaeoripiphorus nuwa gen. et sp. nov. is also suggested.

Falin (2002) indicated his doubt on the monophyly of Ripiphoridae because of the lack of a strong synapomorphy. He hypothesized an early divergence between Ripiphorinae and the ancestral lineage, then Hemirhipidiinae and Ripidiinae became the most derived sister groups and Pelecotominae was considered the most primitive subfamily, though it is possibly a non-monophyletic group. The monophyly of Ripiphoridae is also not supported in recent molecular phylogenetic studies (Gunter et al. 2014; Kergoat et al. 2014; McKenna et al. 2015; Batelka et al. 2016a). Furthermore, Batelka et al. (2016a) recovered paraphyletic Ripiphoridae with Mordellidae as a terminal clade and found Pelecotominae to be sister to remaining ripiphorids and mordellids, with a deep split among pelecotomines and ripiphorid lineages. Ripidiines were regularly found within the clade Ripiphoridae + Mordellidae in a sister relationship to Ripiphorinae + Mordellidae. However, the phylogenetic signal still remains ambiguous despite denser sampling than previous studies. Hence, further phylogenetic analyses combining all fossil and extant taxa are badly needed to examine the monophyly of this family and resolve the relationships among subfamilies, which will give insight into the evolution of wedge-shaped beetles. Our new discovery of Archaeoripiphorus nuwa gen. et sp. nov. not only dates the existence of Ripiphoridae back to the Middle Jurassic but also provides further morphological characters for phylogenetic studies.

\section{Acknowledgments}

We wish to express our hearty thanks to Prof. Dong Ren (College of Life Sciences, Capital Normal University) for loaning specimens. We are also grateful to Dr. Chenyang Cai (Nanjing Institute of Geology and Palaeontology, Chinese Academy of Sciences) and Dr. Adam Ślipiński (CSIRO, Australia) for comments on the placement of the fossil, Dr. Qiang Yang (Sun Yat-Sen University) for his assistance on Paleontology, and Prof. Masahiro Ôhara (Hokkaido University Museum, Japan), Prof. Michael Ivie (Montana State University, USA), Dr. Ming-Luen Jeng (National Museum of Natural Science), Showtaro Kakizoe (Kyushu University, Japan), Mr. Wen-Chuan Liao, Mr. Yi-Siang Lin, Mr. Fu-Shen Huang and Mr. Yu-Tang Wang for their various assistance. This research was supported by the National Natural Science Foundation of China (Grant Nos 31171899, 31572052) and grants from the National Basic Research Program of China (973 Program) (Grant No. 2013CB127600).

\section{References}

Batelka J. 2005. New synonym of the genus Clinops (Coleoptera: Ripiphoridae) with bionomical and distributional notes on C. spectabilis. Folia Heyrovskyana, Series A 13: 27-34. 
Batelka J. 2009. Clinopalpus hanae, a new genus and species of ripiphorid beetle from Malaysia (Coleoptera: Ripiphoridae: Pelecotominae). Acta Entomologica Musei Nationalis Pragae 49 (1): 239245.

Batelka J. 2012. Ptilophorus purcharti sp. nov., the first ripiphorid from Socotra Island, with an account of the biogeography of the Ptilophorini (Coleoptera: Ripiphoridae). Acta Entomologica Musei Nationalis Pragae 52 (Supplementum 2): 269-285.

Batelka J., Kundrata R. \& Bocak L. 2016a. Position and relationships of Ripiphoridae (Coleoptera: Tenebrionoidea) inferred from ribosomal and mitochondrial molecular markers. Annales Zoologici 66 (1): 113-123. http://dx.doi.org/10.3161/00034541ANZ2016.66.1.008

Batelka J., Prokop J. \& Engel M.S. 2016b. New ripiphorid beetles in mid-Cretaceous amber from Myanmar (Coleoptera: Ripiphoridae): First Pelecotominae and possible Mesozoic aggregative behaviour in male Ripidiinae. Cretaceous Research 68: 70-78. http://dx.doi.org/10.1016/j.cretres.2016.08.002

Beutel R.G. \& Friedrich F. 2005. Comparative study of larvae of Tenebrionoidea (Coleoptera: Cucujiformia). European Journal of Entomology 102:241-264. http://dx.doi.org/10.14411/eje.2005.037

Böving A.G. \& Craighead F.C. 1931. An illustrated synopsis of the principal larval forms of the order Coleoptera. Entomologica Americana 11: 1-351. http://dx.doi.org/10.5962/bhl.title.6818

Chang H., Kirejtshuk A.G., Ren D. \& Shih C. 2009a. First fossil click beetles from the middle Jurassic of Inner Mongolia, China (Coleoptera: Elateridae). Annales Zoologici 59 (1): 7-14. http://dx.doi. org/10.3161/000345409X432547

Chang H., Zhao Y. \& Ren D. 2009b. New fossil elaterids (Insect: Coleoptera: Polyphaga: Elateridae) from the Middle Jurassic of Inner Mongolia, China. Progress in Natural Science 19: 1433-1437. http://dx.doi.org/10.1016/j.pnsc.2009.04.006

Chang H., Kirejtshuk A.G. \& Ren D. 2011. On taxonomy and distribution of fossil Cerophytidae (Coleoptera: Elateriformia) with description of a new Mesozoic species of Necromera Martynov 1926. Annales de la Société entomologique de France (N.S.) 47 (1-2): 33-44. http://dx.doi.org/10.1080/0037 $\underline{9271.2011 .10697694}$

Chang H., Nabozhenko M., Pu H., Xu L., Jia S. \& Li T. 2016. First record of fossil comb-clawed beetles of the tribe Cteniopodini (Insecta: Coleoptera: Tenebrionidae) from the Jehol Biota (Yixian formation of China), Lower Cretaceous. Cretaceous Research 57: 289-293. http://dx.doi.org/10.1016/j. cretres.2015.09.001

Cockerell T.D. 1917. Fossil insects. Annals of the Entomological Society of America 10: 1-22.

Crowson R.A. 1995. Some interesting evolutionary parallels in Coleoptera. In: Pakaluk J. \& Ślipiński S.A. (eds) Biology, Phylogeny, and Classification of Coleoptera: Papers Celebrating the 80th Birthday of Roy A. Crowson: 63-85. Muzeum i Instytut Zoologii PAN, Warsaw.

Falin Z.H. 2002. 102. Ripiphoridae Gemminger and Harold 1870 (1853). In: Arnett Jr R.H., Thomas M.K., Skelley P.E. \& Frank J.H. (eds) American Beetles. Volume 2. Polyphaga: Scarabaeoidea through Curculionoidea: 431-444. CRC Press, Boca Raton, Florida.

Falin Z.H. 2003. Phylogenetic Analysis and Revision of the Genera and Subfamilies of the Ripiphoridae (Coleoptera). PhD Thesis, University of Kansas. University Microfilms International, Ann Arbor, Michigan.

Falin Z.H. \& Engel M.S. 2010. Notes on Cretaceous Ripidiini and revised diagnoses of the Ripidiinae, Ripidiini, and Eorhipidiini (Coleoptera: Ripiphoridae). Alavesia 3: 35-42.

Forbes W.T.M. 1926. The wing folding patterns of the Coleoptera. Journal of the New York Entomological Society 34: 42-139. 
Franciscolo M.E. 1962. The genus Glipodes Leconte, 1862 (Coleoptera: Mordellidae) with description of a new species from Venezuela and Costa Rica. Proceedings of the Royal Entomological Society of London B 31: 131-136. http://dx.doi.org/10.1111/j.1365-3113.1962.tb01202.x

Gao K.-Q. \& Ren D. 2006. Radiometric dating of ignimbrite from Inner Mongolia provides no indication of a post-Middle Jurassic Age for the Daohugou Beds. Acta Geologica Sinica 80: 42-45. http://dx.doi. org/10.1111/j.1755-6724.2006.tb00793.x

Gunter N.L., Levkaničová Z., Weir T.H., Ślipiński A., Cameron S.L. \& Bocak L. 2014. Towards a phylogeny of the Tenebrionoidea (Coleoptera). Molecular Phylogenetics and Evolution 79: 305-312. http://dx.doi.org/10.1016/j.ympev.2014.05.028

Han G., Liu Z., Liu X., Mao L., Jacques F. M.B. \& Wang X. 2016. A whole plant herbaceous angiosperm from the Middle Jurassic of China. Acta Geologica Sinica 90: 19-29. http://dx.doi.org/10.1111/1755$\underline{6724.12592}$

Handlirsch A. 1906-1908. Die Fossilen Insekten und die Phylogenie der rezenten Formen: Ein Handbuch für Paläontologen und Zoologen. Verlag Wilhelm Engelmann, Leipzig. http://dx.doi.org/10.5962/bhl. $\underline{\text { title. } 5636}$

Huang D. \& Yang J. 1999. Early Cretaceous fossil Mordellidae (Insecta, Coleoptera) from western Beijing. Acta Palaeontologica Sinica 38 (1): 125-132. [In Chinese with English abstract]

Hudson G.V. 1934. New Zealand Beetles and their Larvae. An Elementary Introduction to the Study of our native Coleoptera. Fergusson and Osborn, Wellington.

Kaupp A., Falin Z. \& Nagel P. 2001. An annotated catalogue of fossil Ripiphoridae, taxonomic notes, and the description of a new genus and species from Baltic amber (Coleoptera: Ripiphoridae: Ripidiinae). Mitteilungen aus dem Geologisch-Paläontologischen Institut der Universität Hamburg 85: 165-195.

Kergoat G.J., Soldati L., Clamens A.L., Jourdan H., Jabbour-Zahab R., Genson G., Bouchard P. \& Condamine F.L. 2014. Higher-level molecular phylogeny of darkling beetles (Coleoptera, Tenebrionoidea, Tenebrionidae). Systematic Entomology 39: 486-499. http://dx.doi.org/10.1111/syen.12065

Kuschel G. 1990. Beetles in a suburban environment: a New Zealand case study. The identity and status of Coleoptera in the natural and modified habitats of Lynfield, Auckland (1974-1989). DSIR Plant Protection Report.

Lacordaire T. 1859. Histoire Naturelle des Insectes. Genera des Coléoptères. Tome 5. Libraire Encyclopédique de Roret, Paris.

Lawrence J.F. \& Newton Jr A.F. 1995. Families and subfamilies of Coleoptera (with selected genera, notes, references and data on family-group names). In: Pakaluk J. \& Ślipiński S.A. (eds) Biology, Phylogeny, and Classification of Coleoptera: Papers Celebrating the 80th Birthday of Roy A. Crowson: 779-1006. Muzeum i Instytut Zoologii PAN, Warsaw.

Lawrence J.F., Falin Z.H. \& Ślipiński A. 2010. 11.8. Ripiphoridae Gemminger and Harold, 1870 (Gerstaecker, 1855). In: Beutel R.G. \& Leschen R.A.B. (eds) Handbuch der Zoologie / Handbook of Zoology. Insecta: Coleoptera, Beetles. Vol. 2: 538-548. W. de Gruyter, Berlin.

Liu Z.-J. \& Wang X. 2016. Yuhania: a unique angiosperm from the Middle Jurassic of Inner Mongolia, China. Historical Biology: 1-11. http://dx.doi.org/10.1080/08912963.2016.1178740

Liu M., Lu W. \& Ren D. 2007. A new fossil mordellid (Coleoptera: Tenebrionoidea: Mordellidae) from the Yixian Formation of Western Liaoning Province, China. Zootaxa 1415: 49-56.

Liu M., Zhao Y. \& Ren D. 2008. Discovery of three new mordellids (Coleoptera: Tenebrionoidea) from the Yixian Formation of western Liaoning, China. Cretaceous Research 29: 445-450. http://dx.doi. org/10.1016/j.cretres.2008.01.006 
HSIAO Y. et al., The first fossil Ripiphoridae from the middle Jurassic of China

McKenna D.D., Wild A.L., Kanda K., Bellamy C.L., Beutel R.G., Caterino M.S., Farnum C.W., Hawks D.C., Ivie M.A., Jameson M.L., Leschen R.A.B., Marvaldi A.E., McHugh J.V., Newton A.F., Robertson J.A., Thayer M.K., Whiting M.F., Lawrence J.F., Ślipiński A., Maddison D.R. \& Farrell B.D. 2015. The beetle tree of life reveals that Coleoptera survived end-Permian mass extinction to diversify during the Cretaceous terrestrial revolution. Systematic Entomology 40: 835-880. http://dx.doi.org/10.1111/ syen. 12132

Mi J., Sun C., Sun Y., Cui S. \& Ai Y. 1996. Early-Middle Jurassic Phytoecology and Coalaccumulating Environments in Northern Hebei and Western Liaoning. Geological Publishing House, Beijing. [In Chinese]

Pan X., Chang H., Ren D. \& Shih C. 2011. The first fossil buprestids from the Middle Jurassic Jiulongshan Formation of China (Coleoptera: Buprestidae). Zootaxa 2745: 53-62.

Perrichot V., Nel A. \& Neraudeau D. 2004. Two new wedge-shaped beetles in Albo-Cenomanian ambers of France (Coleoptera: Ripiphoridae: Ripiphorinae). European Journal of Entomology 101: 577-581. http://dx.doi.org/10.14411/eje.2004.081

Ren D. \& Krzeminski W. 2002. Eoptychopteridae (Diptera) from the Middle Jurassic of China. Annales Zoologici 52 (2): 207-210.

Ren D., Tan J., Shih C. \& Gao T. 2010. Chapter 2. The Upper Mesozoic stratigraphic characteristics in northeastern China. In: Ren D., Shih C., Gao T., Yao Y. \& Zhao Y. (eds) Silent Stories-Insect Fossil Treasures from Dinosaur Era of the Northeastern China: 12-21. Science Press, Beijing.

Selander R.B. 1957. The systematic position of the genus Nephrites and the phylogenetic relationships of the higher groups of Rhipiphoridae (Coleoptera). Annals of the Entomological Society of America 50: 88-103. http://dx.doi.org/10.1093/aesa/50.1.88

Švácha P. 1994. Bionomics, behaviour and immature stages of Pelecotoma fennica (Paykull) (Coleoptera: Rhipiphoridae). Journal of Natural History 28: 585-618. http://dx.doi.org/10.1080/00222939400770271

Tan J., Chang H., Yue Y., Shih C. \& Ren D. 2010. Chapter 18. Coleoptera-Sacred, Precious and Strong. In: Ren D., Shih C., Gao T., Yao Y. \& Zhao Y. (eds) Silent Stories-Insect Fossil Treasures from Dinosaur Era of the Northeastern China: 180-215. Science Press, Beijing.

Wang B. \& Zhang H. 2011. The oldest Tenebrionoidea (Coleoptera) from the Middle Jurassic of China. Journal of Paleontology 85 (2): 266-270. http://dx.doi.org/10.1666/09-088.1

Wang W.-L. 1993. On Liaoximordellidae fam. nov. (Coleoptera, Insecta) from the Jurassic of Western Liaoning Province, China. Acta Geologica Sinica 67 (1): 86-94. [In Chinese]

Watt J.C. 1983. The huhu Prionoplus reticularis (Cerambycidae) and other Coleoptera in Acacia. New Zealand Entomologist 7: 364-365. http://dx.doi.org/10.1080/00779962.1983.9722425

Manuscript received: 21 April 2016

Manuscript accepted: 27 June 2016

Published on: 14 February 2017

Topic editor: Christian de Muizon

Desk editors: Jeroen Venderickx and Kristiaan Hoedemakers

Printed versions of all papers are also deposited in the libraries of the institutes that are members of the EJT consortium: Muséum national d'Histoire naturelle, Paris, France; Botanic Garden Meise, Belgium; Royal Museum for Central Africa, Tervuren, Belgium; Natural History Museum, London, United Kingdom; Royal Belgian Institute of Natural Sciences, Brussels, Belgium; Natural History Museum of Denmark, Copenhagen, Denmark; Naturalis Biodiversity Center, Leiden, the Netherlands. 